\title{
Ajnowie, górale i Bronisław Piłsudski. O wystawie
}

\author{
DOI: $10.19195 / 1429-4168.23 .19$
}

Całe ponad 18 lat mojego pobytu na Dalekim Wschodzie miało miejsce wbrew mojej woli. Ustawicznie tęskniąc za powrotem do mojej ojczyzny, starałem się wyrzucić z siebie bolesne uczucie bycia wygnańcem — zniewolonym i siłą wyrwanym z tego, co mi było najdroższym. Tedy naturalnie zainteresowałem się tubylcami Sachalinu, którzy jako jedyni prawdziwie kochali ten kraj, miejsce ich bytowania od czasów niepamiętnych, znienawidzone teraz i zbrukane przez tych, którzy uczynili zeń karną kolonię. Wchodząc w kontakt z tymi dziećmi natury, których inwazja totalnie obcej formy cywilizacji zaskoczyła i oszołomiła, wiedziałem, że pomimo bycia pozbawionym wszelkich praw i w najgorszych latach mojego istnienia jednak mam jakąś moc i możliwość niesienia im pomocy. [...] Odczuwałem głęboką przyjemność $\mathrm{z}$ rozmowy z ludźmi innej rasy w ich własnym języku ${ }^{1}$.

[W] obliczu nieuchronnego wymarcia w najbliższych dekadach około połowy spośród około 6500-7000 języków świata i kultur ich użytkowników nauka uznała każdy język i każdą kulturę za niezbywalną część dziedzictwa całej ludzkości, każdą śmierć języka i każdą śmierć odrębnej lokalnej kultury za nieodwracalną stratę i tragedię ekologiczną w wymiarze ogólnoludzkim, zachowanie zaś tych walorów - nawet jeśli tylko w formie spetryfikowanej (w postaci rejestracji pisemnej czy audiowizualnej) — za priorytet czy wręcz imperatyw badawczy. W historii nauki właśnie takie wyniki okazały się najtrwalsze².

W 1906 roku Bronisław Piłsudski (1866-1918) — zesłaniec, etnograf, muzealnik, od dziesięciu lat badacz Ajnów i innych rdzennych mieszkańców Sachalinu i Hokkaido, przyjechał do Zakopanego. Zjawił się pod Tatrami w szczególnym momencie — gdy fascynacja góralszczyzną osiągała apogeum, a mit górala na stałe wpisywał się w polską kulturę. Etnograf słusznie zauważył, iż co prawda

nie jest tu jeszcze ten szczery kraj rodzinny, jak nasza Litwa. Lecz tu dużo ludzi, co się czują sami cudzo, co nie mają silnej i szczerej łączności z tą ziemią, lecz zawsze to już Europa, to Polska ${ }^{3}$.

„Góralskie” widzenie Piłsudskiego uformowały sugestywna wizja Stanisława Witkiewicza, jego arcydzieło Na przełęczy. Wrażenia i obrazy z Tatr oraz „styl zakopiański”. Piłsudski przeczytał Na przelęczy i — podobnie jak wielu w owym czasie miłośników Tatr — głęboko je przeżył ${ }^{4}$.

${ }^{1}$ B. Piłsudski, Materiały do studiów nad językiem i folklorem Ajnów, Kraków 1912, cyt. za: A.F. Majewicz, „Za serdeczny uśmiech rozbawionych dzieci, za łzy wzruszenia - za ten balsam..." - istota i waga naukowego dziedzictwa Bronisława Pitsudskiego, [w:] Ajnowie, górale i Bronisław Pitsudski, red. A. Król, Kraków 2018, s. 19-20.

${ }^{2}$ A.F. Majewicz, op. cit., s. 16.

3 Z. Wójcik, Z nieznanej korespondencji zesłańczej Bronisława Piłsudskiego, „Niepodległość i Pamięć" 1996, nr 2, s. 158.

${ }^{4} \mathrm{O}$ związkach Bronisława Piłsudskiego ze Stanisławem Witkiewiczem zob. „Kochany wujaszku”. Listy Bronisława Pitsudskiego do Stanisława Witkiewicza, oprac. A. Kuczyński, Zakopane-Sulejówek 2016.

Wrocławskie Studia Wschodnie 23, 2019

(C) for this edition by CNS 
Czy zainteresowałby się szeroko rozumianą góralszczyzną, gdyby nie jego zesłańcze, przede wszystkim ajnuskie doświadczenie? Nie wiadomo. Bez wątpienia kontakt z tym wyjątkowym ludem i próba ocalenia jego tradycji oraz sposobu życia na Sachalinie i Hokkaido uwrażliwiły etnografa na „upadłe, ginące kultury”, ulegające na początku XX wieku gwałtownej akulturacji. Unikatowa kultura górali podtatrzańskich ewoluowała, zmieniając się nieodwracalnie. Przenikliwie zdiagnozował to zjawisko Stanisław Witkiewicz, pisząc:

My przychodzimy do ludu, który za górami i lasami, ukryty w chmurach, żył życiem samodzielnym, wytworzył lub rozwinął i wykończył pewne kształty estetyczne, i zamiast dalej rozwijać i prowadzić jego robotę, przystosowując ją do bardziej skomplikowanych potrzeb, my wnosimy jałowość, bezbarwność, ubóstwo artystyczne bogatszych klas naszego społeczeństwa ${ }^{6}$.

NatomiastAjnowie, bezwzględnie niszczeni zarówno przez Japończyków,jak i przez Rosjan, zapewne zniknęliby bezpowrotnie, gdyby nie między innymi Bronisław Piłsudski — zesłaniec współczujący i współodczuwający. Działo się tak zapewne dlatego, że

[Bronisław Piłsudski i Wacław Sieroszewski] mogli się identyfikować jedynie z rodzimym ludem żyjącym pomiędzy dwoma wielkimi i agresywnymi potęgami bez ochrony aparatu prawnego zapewnianego przez własne państwo. [...] Niewykluczone, że Piłsudski i Sieroszewski mieli podobne wyobrażenie o swoim nadwątlonym statusie Polaków. Choć relacje te można łatwo krytykować za pusty patos, zaciemniający ich faktyczne działania podejmowane w imieniu Rosji, wskazują one jednak na ogólniejszą zdolność do postrzegania siebie samego jako Innego ${ }^{7}$.

„Ajnowie, górale i Bronisław Piłsudski”8, wystawa dedykowana Bronisławowi Piłsudskiemu w stulecie śmierci, zorganizowana w Muzeum Sztuki i Techniki Japońskiej Manggha w Krakowie w setną rocznicę odzyskania przez Polskę niepodległości, po raz pierwszy przedstawiła w jednej, otwartej przestrzeni muzealnej ślady tych dwóch wyjątkowych kultur, które mimo iż istnieją w odmiennych warunkach i przestrzeniach, wydają się sobie bliskie. Choćby z tego powodu, że ich upodobania artystyczne są podobne, a „każda rzecz powszedniego użytku jest upiększoną"9.

$\mathrm{Na}$ wystawie zaprezentowano owe kultury poprzez wizualny dorobek Bronisława Piłsudskiego: fotografie utrwalające mieszkańców kotanów i ich zwyczaje, przedmioty codziennego użytku z okręgu Nibutani-Biratori na Hokkaido, gdzie Piłsudski prowadził badania i tworzył kolekcję, a także zbiór etnograficzny związany z góralami podhalańskimi z Muzeum Tatrzańskiego w Zakopanem.

Wystawa przedstawiała dwa tematy — „Ajnowie” i „Górale” — ukazane w dwóch przestrzeniach, a spotykające się w kilku punktach. Jednym z takich symbolicznych łączników jest portret Bronisława Piłsudskiego namalowany przez litewskiego mala-

${ }^{5}$ W liście z 25 lipca 1912 roku do Stanisława Witkiewicza Piłsudski pisał: „Ja nastaję na spieszność zbiorów upadłej ginącej kultury — widzę naocznie przy zetknięciu z ludnością, jak szybko ginie sporo cennych rzeczy" - cyt. za: ibidem, s. 38.

6 S. Witkiewicz, Na przełęczy. Wrażenia i obrazy z Tatr, Warszawa 1891, s. 23.

${ }^{7}$ D. Crowley, Seeing Japan, imagining Poland: Polish art and the Russo-Japanese war, „The Russian Review” 67, 2008, s. 67.

${ }^{8}$ Scenariusz i aranżacja plastyczna wystawy: dr Anna Król; druki towarzyszące wystawie: Rafał Sosin.

9 S. Witkiewicz, Na przetęczy..., s. 21.

Wrocławskie Studia Wschodnie 23, 2019

(C) for this edition by CNS 
rza Adomasa Varnasa (1879-1979) w 1912 roku w Zakopanem, w domu Stefana Żeromskiego, przedstawiający etnografa $\mathrm{w}$ wykonanej $\mathrm{z}$ włókien pokrzywy przez jego ajnuską żonę Chūhsammę ajnuskiej szacie z malowaną bordiurą $\mathrm{z}$ ornamentem ajnuskim $^{10}$.

Kulturę Ajnów Piłsudski dokumentował w rozmaity sposób, wykorzystując osiągnięcia techniki, między innymi fonograf Edisona, do zanotowania muzyki, pieśni i podań ajnuskich. Wykonał także wiele fotografii, zarówno etnograficznych, jak i reportażowych, które sprzedawał do różnych muzeów świata. Dlatego też narrację przestrzeni zatytułowanej „Ajnowie” budują unikatowe w skali światowej zdjęcia wykonane przez Bronisława Piłsudskiego na Sachalinie, ofiarowane Katedrze Antropologii Uniwersytetu Jagiellońskiego, przechowywane w Zakładzie Antropologii Instytutu Zoologii i Badań Biomedycznych UJ. Część tego zbioru opublikowano wcześniej, w 2008 roku w jubileuszowym numerze „Alma Mater” z okazji obchodów stulecia powołania do życia Katedry Antropologii na Uniwersytecie Jagiellońskim ${ }^{11}$. Te niezwykłe fotografie, opatrzone odręcznymi komentarzami etnografa, po raz pierwszy zostały teraz przedstawione szerokiej publiczności na wystawie w Muzeum Manggha. W przestrzeni „Ajnowie” zasygnalizowano dwa miejsca: „Sachalin” i „Hokkaido”.

Bronisław Piłsudski zetknął się z Ajnami po raz pierwszy zapewne latem 1896 roku na Sachalinie w okręgu korsakowskim. Tu, w kotanie Ai, spotkał swoją ajnuską żonę Chūhsammę. Materiały etnograficzne dotyczące Ajnów sachalińskich — przedmioty kultu, narzędzia, ubrania - zbierane przez Piłsudskiego znajdują się przede wszystkim w kolekcjach muzeów rosyjskich: w Muzeum Antropologii i Etnografii im. Piotra Wielkiego w Sankt Petersburgu (Kunstkamera), we Władywostoku i w Muzeum na Sachalinie, a także w kolekcjach prywatnych.

Natomiast w Hokkaido Bronisław Piłsudski z Wacławem Sieroszewskim i ajnuskim thumaczem Taroncim przebywali od lipca do końca września 1903 roku, prowadząc badania nad Ajnami. Szczegółowy opis ich pobytu wśród tego ludu Sieroszewski zamieścił w swojej książce reportażowej Wśród kosmatych ludzi, później okres ten zrekonstruował Kōichi Inoue ${ }^{12}$. Około tygodnia spędzili w Biratori, prowadząc intensywne badania etnograficzne. Co prawda, pobyt tam trwał krótko, jednakże był niezwykle owocny. Piłsudski wielokrotnie wykorzystywał zebrane w Biratori materiały.

W 1992 roku w Nibutani otwarto Muzeum Kultury Ajnów. Z tego właśnie muzeum prezentowaliśmy kolekcję przedmiotów związanych z życiem i kulturą Ajnów, nie tylko ich stroje, przedmioty kultu, ale też zabawki dziecięce. Do najpiękniejszych i najcenniejszych należały stroje wierzchnie (attus-amip), wykonane z włókien pokrzywy, zdobione charakterystycznym, geometrycznym ornamentem, a także szaty typu chijiri

${ }^{10}$ Zob. K. Inoue, Pitsudskiana japonica 2018. Upamiętnienie stulecia śmierci Bronisława Pitsudskiego, [w:] Ajnowie, górale i Bronisław Piłsudski..., s. 51-52.

11 K. Szostek, Ajnowie w obiektywie Bronisława Piłsudskiego, „Alma Mater” 2008, nr 106, s. $55-68$.

12 K. Inoue, The Ainu expedition to Hokkaido in 1903, red. K. Sawada, K. Inoue, [w:] A Critical Biography of Bronisław Pitsudski, red. K. Sawada, K. Inoue, W. Kowalski, Tokyo 2010, t. 2, s. 3-37.

Wrocławskie Studia Wschodnie 23, 2019

(C) for this edition by $\mathrm{CNS}$ 
(wykonane z importowanej bawełny, ozdobione haftem)_oraz pogrzebowe (kapar-amip). Uzupełniały je nakrycia głowy i ramion (konci), naszyjnik (tamasay) i kolczyki (ninkari). Niemal wszystkie pochodzą z XIX wieku i odpowiadają kolekcji zgromadzonej wówczas przez Bronisława Piłsudskiego. Region ten był bliski Piłsudskiemu i Sieroszewskiemu, gdyż

Wśród gęstej ludności japońskiej wkropione były tu i owdzie resztki Ajnów, maluchne wioski $\mathrm{z}$ dwóch-trzech trzcinowych chałup, nakrytych wielkimi trzcinowymi dachami o stopniowanym poszyciu, podobnym do polskich strzech [...] wtedy było tak pięknie i ukryte w zieleni chaty sprawiały takie malownicze, czysto polskie wrażenie ${ }^{13}$.

W przestrzeni „Górale” prezentujemy kolekcję zgromadzoną przez Bronisława Piłsudskiego dla Muzeum Tatrzańskiego, o której Anna Kozak pisze:

Efektem [...] działalności Bronisława Piłsudskiego jest dziś muzealny zbiór artefaktów z różnych dziedzin kultury Podtatrza, liczący 147 przedmiotów. Najwięcej jest w nim elementów ubioru ludowego i galanterii służącej do jego ozdoby, na przykład kobiece naszyjniki, nieobecne do tej pory w zbiorach Muzeum. Skromniejszy liczbowo jest zbiór sprzętów domowych, wśród których nowością jest między innymi łapka na gryzonie. Obok zgromadzonych elementów warsztatów tkackich i tych związanych z obróbką drewna znalazła się pierwsza forma do robienia fajek. Piłsudskiego interesowała również sztuka ludowa. Oprócz obrazów na szkle i rzeźby nabył do zbiorów drzeworyt, obraz na blasze, przykłady malarstwa olejnego na płótnie. Kupował również popularne w środowisku wiejskim oleodruki, przez większość kolekcjonerów pogardzane, bo uważane za przykład brzydoty i tandety. Z dziedziny miejscowego gospodarowania interesującym obiektem okazała się kłonia jednorękojeściowa znaleziona w Witowie, wykorzystywana do łowienia ryb w płytkich potokach — w zbiorach Muzeum Tatrzańskiego niepowtarzalna. [...]

Dziś zbiory etnograficzne Muzeum Tatrzańskiego liczą ponad 11 tysięcy przedmiotów, a zbiór artefaktów zgromadzony staraniem Piłsudskiego stanowi ich niewielką, choć istotną cząstkę. Niektóre ze zgromadzonych w nim zabytków zaowocowały mniejszymi lub większymi kolekcjami, między innymi ludowych drzeworytów, obrazów na szkle, oleodruków, pierścionków, zamków, kłódek i kluczy. Inne znów są całkowicie unikatowe, w zasobach Muzeum niepowtarzalne i przez to szczególnie cenne. Należą do nich obiekty z dziedziny rybołówstwa i pszczelarstwa, wykonane przez dzieci zabawki, akcesoria związane z paleniem tytoniu, pieczęcie do znakowania płótna czy pewne elementy uprzęży końskich ${ }^{14}$.

Tę przestrzeń dopełniają fotograficzne portrety Bronisława Piłsudskiego wykonane przez Stanisława Ignacego Witkiewicza (1885-1939) w Zakopanem w 1912 roku oraz fotografia zaginionego portretu olejnego etnografa na tle obrazów na szkle z jego podhalańskiego kolekcji, namalowanego przez Witkacego.

Piłsudski dostrzegł wyjątkowość obu kultur, ich odrębność, wręcz prymarność, a przede wszystkim zobaczył w nich ajnów — ludzi.

Prace na wystawę wypożyczono od kolekcjonerów prywatnych (Londyn, Zakopane), Stefana Okołowicza (3 fotografie), z Archiwum Narodowego w Krakowie

13 W. Sieroszewski, Wśród kosmatych ludzi, Warszawa 1932, s. 15, 29.

14 A. Kozak, Zakopiańska kolekcja Bronisława Piłsudskiego, [w:] Ajnowie, górale i Bronistaw Pitsudski..., s. 180, 183.

Wrocławskie Studia Wschodnie 23, 2019

(C) for this edition by CNS 
(4 fotografie), Biblioteki Naukowej PAU i PAN w Krakowie (album zawierający 189 fotografii i 22 zdjęcia z różnych zbiorów), Fundacji Rodziny Józefa Piłsudskiego (1 obraz), Muzeum Kultury Ajnów w Nibutani (Biratori) (42 obiekty), Japonia (49 obiektów), Muzeum Tatrzańskiego im. dra Tytusa Chałubińskiego w Zakopanem (180 obiektów) oraz Zakładu Antropologii Instytutu Zoologii i Badań Biomedycznych Uniwersytetu Jagiellońskiego (57 fotografii).

Wystawie towarzyszy albumowa polsko-angielska publikacja pod tytułem Anjowie, górale i Bronisław Pitsudski, pod redakcją Anny Król, w której po raz pierwszy została opublikowana zarówno góralska kolekcja w Muzeum Tatrzańskiego, jak i szeroko omówione fotografie Ajnów wykonane przez Piłsudskiego oraz zbiór rzemiosła artystycznego ajnuskiego z Nibutani-Biratori. Teksty prof. Alfreda F. Majewicza, prof. Kōichiego Inoue, prof. Kazuhiko Sawady, dr Anny Król, Lesława Dalla i Anny Kozak możliwie szczegółowo przedstawiają Bronisława Piłsudskiego.

Anna Król

\section{Międzynarodowa Konferencja Poświęcona Bronisławowi Piłsudskiemu i Jego Dziedzictwu Naukowemu /} IV International Conference on Bronisław Piłsudski and His Scholarly Heritage. Bronisław Piłsudski: On the Centennial of His Death. Towards an Independent Homeland

DOI: $10.19195 / 1429-4168.23 .20$

W dniach 18-19 października 2018 roku w Muzeum Sztuki i Techniki Japońskiej Manggha w Krakowie odbyła się IV Międzynarodowa Konferencja Poświęcona Bronisławowi Piłsudskiemu i Jego Dziedzictwu Naukowemu (IV International Conference on Bronisław Piłsudski and His Scholarly Heritage). Zarówno czas, jak i miejsce konferencji nie były przypadkowe. W 2018 roku, wraz ze stuleciem odzyskania przez Polskę niepodległości, obchodziliśmy także setną rocznicę śmierci Bronisława Piłsudskiego - prywatnie brata marszałka, lecz przede wszystkim wybitnego badacza kultur ludów syberyjskich, w tym Ajnów mieszkających na rosyjskim Sachalinie i na japońskiej wyspie Hokkaido.

Konferencja poświęcona Bronisławowi Piłsudskiemu (4IBPC — 4th International Bronisław Piłsudski Conference) ma charakter cykliczny. Jej poprzednie edycje sięgają jeszcze lat osiemdziesiątych XX wieku i odbyły się w różnych miejscach globu: 1IBPC - 1985, Sapporo-Nibutani, 2IBPC — 1991, Jużnosachalińsk-Nogliki, 3IBPC - 1999, Kraków-Zakopane. 